\title{
THE INCREASING PHENOMENON OF SECOND-HAND CLOTHES PURCHASE: INSIGHTS FROM THE LITERATURE
}

\author{
Halimin Herjanto ${ }^{1}$, Jean Scheller-Sampson ${ }^{1}$, Elisabeth Erickson ${ }^{1}$ \\ ${ }^{1}$ McKendree University School of Business, McKendree University \\ 701 College Road, Lebanon, IL 62254 \\ * Correspnding author; Email: hherjanto@mckendree.edu
}

\begin{abstract}
The global trend of second-hand clothing (SHC) consumption is significantly increasing and unstoppable. This trend has made, and will continue to make, a huge impact in the clothing industry in virtually every part of the world. However, the number of studies on SHC are still limited and more importantly, the findings are mixed and inconclusive. This study investigates the trend in SHC research between 1990 and 2014. 131 published academic articles from different disciplines were collected and content analyzed and the results indicate that SHC research was highly focused on the topics of consumption behavior, textile disposal behavior, and SHC trading related issues. In addition, the results also show that SHC research was mainly conducted from the consumers' point of view. With the increasing interest in SHC, this study attempts to develop a better understanding of SHC phenomena and provide clear future research directions to scholars in designing SHC related research.
\end{abstract}

Keywords: Second-hand consumption, consumption behavior, disposal behavior, content analysis.

\section{Introduction}

In modern society, the wearers of the clothes are now subject to society's scrutiny and approval or disapproval (Hansen, 2000). Approval supports individuals' self-image (Kressmann et al., 2006), self-love (Sontag \& Lee, 2004), comfort (De Klerk \& Tselepis, 2007) and positive emotion experience (Kang, Kim, $\&$ Kim, 2013). Such contemporary motivations encourage the desire for approval (Brooks, 2012) and the purchase of more clothes (Rahman, Jiang \& Liu, 2010). As a consequence, global textiles and the clothing business are worth nearly USD $\$ 3,000$ trillion dollars (Business 2 Community, 2015). Despite this significant figure, Wright (2014) argues that in fact, the global clothing industry has failed to reach its maximum sales potential. This failure is a result of the global economic recession (Wright, 2014) and political instability (Hansen, 1999). As a response to these factors, consumers' have developed a higher appreciation of the value of reusable clothes (Rucker et al., 1995) which has subsequently provided a strong new business opportunity and increased the global sales of SHC to nearly USD \$200 billion per year (Slotterback, 2007). Mintel (2009) argues that this trend is unstoppable and is increasing every year, and as a result he predicts that the world's consumption of SHC will more than double in the next few years.

Today, SHC are no longer seen as a low level fashion; instead, they have become a global fashion trend and customers from different socio-economic backgrounds (Hansen, 2000) and classes (Milgram, 2012), including artists (Apatoff, 2014) and high profile individuals (Huffpost, 2013) such as expats, tourists, and royal family members (Besnier, 2004) buy and wear SHC comfortably. This trend suggests that SHC offer something of value to everyone (Besnier, 2004) and therefore has boosted the number of second-hand retailers (Ward, 2011). In an effort to fully understand the SHC phenomenon, scholars in the fashion and marketing disciplines have investigated the issues in terms of both internal and external components (Walter, 2008). Internal components include economic factors (Baden \& Barber, 2005), social factors (Beard, 2008), psychological factors (Castillo, 2014), demographic factors (Bianchi \& Birtwistle, 2012; Birtwistle \& Moore, 2007), and culture (Na'amneh \& Al Huban, 2012). External components, on the other hand, include recycle facilities (Abimola, 2012), government regulations (Haggblade, 1990), and distribution channels (Mhango \& Niehm, 2005). Despite the amount of research, scholars argue that the number of studies on SHC are still both limited (Na'amneh \& Al Huban, 2012) and sporadic (Walter, 2008), and the findings are mixed and lack agreement (Felix, Asuamah \& Darkwa, 2013). Scholars believe that this lack of agreement is due to the informal and unstructured nature of SHC transactions (Roux \& Guiot, 2008), narrow research topics (Jagel, Keeling, Reppel \& Gruber, 2012) and the employment of different research methodologies (Beard, 2008). Thus, to resolve this issue $\mathrm{Xu}$, Chen, Burman 
and Zhao (2014) suggest that deeper investigations on this issue are urgently required. To answer their call and increase understanding of the SHC phenomenon, it is felt that there is a need to take a step back and consolidate existing research inventories. Such consolidation provides an opportunity to identify the research trends and more importantly, an opportunity to establish a clearer direction for future research (Gaur, Herjanto \& Makkar, 2014). Therefore, this study content analyzed 131 researches on SHC published over the years 1990-2014.

Slotterback (2007) asserts that the 1990s began an important era in modern SHC consumption. During the 1990s, modern SHC trading emerged and gained a global popularity, with almost every country in the world becoming actively involved in the SHC industry either as traders or consumers. Thus, it is important to investigate the research stock published from this time period in connection with what we know about the history of SHC, SHC consumption, textile disposal behavior, and SHC trading related issues and offer new suggestions on how and what topic should be focused on in order to develop new theoretical frameworks to appreciate the SHC phenomenon in the future. This study is organized as follows: first, we present a background to the SHC definition. Secondly, we discuss our methodology used in this study. Thirdly, we explain what we know about the history of SHC consumption, consumption behavior, disposal behavior, and trading related issues. Fourthly, we present a discussion on what we do not know about the SHC phenomenon. Lastly, we present a conclusion and the limitations of this study.

\section{Research Method}

Initially, published SHC related articles on Google Scholar were researched. According to Jucso (2008), Google Scholar offers wide academic journal coverage. In addition, Noruzi (2005) argues that Google Scholar provides instant results, less bias in journal selection, and report findings from multiple years. Accordingly, Linacre (2013) suggests that Google Scholar enhances researchers' ability to conduct broader, conclusive, and multidisciplinary searchers. The words "second-hand clothes", "recycled clothes", "used clothes", and "cast off clothes" were inputted as keywords, which resulted in several thousand published articles ranging from 1990 to 2014. From this reserve, all conferences, proceeding papers, unpublished Master and Doctoral dissertations, book chapters, and unpublished working papers were removed. Further, the abstracts were conscientiously reviewed by two researchers to remove papers which did not directly relate to the SHC topic. This elimination resulted in the identification of 131 research articles from various academic journals and different disciplines, which comprised the sample for further analysis.

Content analysis was then performed on selected research articles to identify and understand the trends in SHC. Each published article was classified and coded in accordance with Walter's (2004) recycling categorization, which included SHC consumption behavior, textile disposal behavior, and SHC trading related issues. Following Holsti's (1969) recommendation, inter-coder reliability and judgments were conducted. The reliability coefficient was satisfactorily found and met Holsti's minimum threshold value of $85 \%$. A history of SHC was found to be $98 \%$. The reliability coefficient of SHC consumption behavior and textile disposal behavior was $100 \%$ and $98 \%$ respectively. Finally, the coder reliability for SHC trading was $95 \%$.

\section{Findings \& Discussion}

\section{The History of SHC is the Foundation of Understanding the Phenomenon}

SHC has a long history that can be tracked back to mid-1300 Europe (Seidel, 1991). At this time, Europe was experiencing a deep economic depresssion, increasing populations, political and social rebellions, and severe famine and mass starvation (Smitha, 2015). Due to these deteriorating economic and living situations, SHC become an important alternative to fulfil ordinary consumers' clothing needs (Lemire, 2006; Barahona \& Sanchez, 2012). In such difficult times, the circulation of SHC reached consumers through four important ways.

Firstly, clothes were inherited from the estate of deceased family members or masters (Lambert, 2004) to liquidate or settle their debts (Van Damme \& Vermoesen, 2009) or in exchange for other goods (Hansen, 2000) and to make profit for the defendants (Seidel, 1991). Secondly, SHC were given to family members as patrimony (Charpy, 2008) or memorabilia (Lambert, 2014) or as a gift (Barahona \& Sanchez, 2012). Thirdly, consumers obtained SHC from remade or repaired old clothes (Lemire, 2006), for instance, a mother altered her clothes to give to her daughters or remodeled them to fit the current fashion (Benson, 2007). Finally, consumers bought their SHC from SHC retailers (Lemire, 2006).

Noon (2011) suggests that these retailers could be grouped into three different categories: clothes bro- 
kers, pawnbrokers, and those who held a roup or a simple auction. Clothes brokers were known as tailors who altered or remodeled existing clothes to meet the needs of their consumers - mainly middle class (Barahona \& Sanchez, 2012). Pawnbrokers, on the other hand, sold or hired out SHC to underworld consumers and mob members (Ginsburg, 1980). Finally, those who held a roup or simple auction sold SHC on a bargaining basis - a popular method of acquisition among bargain hunters (Noon, 2011). Barahona and Sanchez (2012) further point out that the popularity of SHC also created a new business called Mauleros or remnant sellers who supported SHC customers by selling bits and pieces of second-hand fabrics which could be used for repairing SHC. Today, SHC are widely available at thrift shops, flea markets, secondhand shops, vintage shops, auctions and garage sales (Ruckers et al., 1995), yard sales (Steinbring \& Ruckers, 2003), special SHC markets (Besnier, 2004), local and traditional markets (Hansen, 1999), and the Internet (Charbonneau, 2008).

Thus, understanding such history is a fundamental ingredient for one's learning and development (Blank, 2015), and helps researchers and policy makers to identify the structure, genuine constraints, historical trends, and more importantly, to find the answers to the SHC phenomenon and prepare for the future (Stearns, 2013). Brief history of SHC is presented in Table 1.

\section{Consumers'SHC Consumption Behavior}

The consumption of SHC is unique (Beard, 2008) and complex (Ha-Brookshire \& Hodges,
2009). This complexity is due to the fact that customers have to go through different stages of acquisition - for example; a product information search including previous ownership (Farrant, Olsen \& Wangel, 2011), that is, how the previous owners' purchased, used, stored and disposed their clothes (Winakor, 1969). To understand SHC consumption behavior, Van Birgelen, Semeijn and Keicher (2009) suggest that firstly, it is important to understand customer's disposable behavior. Following their suggestion, this section starts with a discussion on clothing disposable behavior and follows this with a discussion on SHC acquisition behavior.

\section{SHC Disposal Behavior}

SHC disposable behavior occurs when the original owner of the clothes no longer wants to keep his/ her clothes (Brookshire \& Hodges, 2009). The extant literature shows that there are several ways to get rid of unwanted clothes. These include (1) ridding where the clothes are beyond repair and there is no way to reuse them. In this case, clothes are usually thrown away and end up at the landfill (Albinsson \& Parera, 2009). (2) Recycling - in which the condition of clothes is reasonably good and they are still usable. The original owner of these clothes tends to take these clothes either to a recycle shop or to a charity shop (Parsons, 1999). (3) Donating - the original owner usually drops his/her clothes off to a charity shop, or to a religious or charity organization (Ekstrom \& Salomonson, 2014). (4) Sharing and (5) exchanging occur when the original owner is willing to share or exchange his/her unwanted clothes within his/her

Table 1

History of SHC

\begin{tabular}{lll}
\hline Authors & Contributions & Place \\
\hline Ginsburg (1980) & $\begin{array}{l}\text { Examines the SHC trading situation in England between 1700 and 1978. The study } \\
\text { found that SHC businesses were regarded as an essential infrastructure to support } \\
\text { ordinary consumers and explained the contribution of SHC to consumers' welfare. }\end{array}$ \\
\hline Huck (2003) & $\begin{array}{l}\text { Explores the functions of SHC in Ireland during the1800s. This study discovered that } \\
\text { clothes represent wearers' level of economic and social power and core identity. }\end{array}$ \\
\hline Lemire (2006) & $\begin{array}{l}\text { Investigates second-hand consumption trends in Europe between1600 and 1850. This Europe } \\
\text { study revealed that the evolution of SHC went through 3 stages: transition from } \\
\text { scarcity, growing abundance, and industrial plenty. }\end{array}$ \\
\hline Benson (2007) & $\begin{array}{l}\text { Examines American middle-class SHC consumption. The study found that during the USA } \\
\text { interwar era, the dominant type of SHC in the market was women's and children's } \\
\text { wear. }\end{array}$ \\
\hline Barahona \& Sanchez & $\begin{array}{l}\text { Scrutinize the role of SHC in the survival strategy of Spanish low income consumers Spain } \\
\text { in the 1800s. This study found that such customers survived by recycling their clothes } \\
\text { across generations and for donations. }\end{array}$ \\
\hline
\end{tabular}


network or to community members (Albinsson \& Parera, 2009). Finally, (6) reselling - where the owner sells his/her unwanted clothes to consignment shops, garage sales (Walter, 2008), or at car boot sales (Hibbert, Horne \& Tagg, 2005). Lastovicka and Fernandez (2005) found that such wide availability of disposal channels promotes a high level of unwanted clothes. As a result, in mid-2010, the US, Europe (Lu, 2015) and Japan (Ohno, 2011) produced nearly $2 \mathrm{M}$ tons of SHC.

In addition, SHC disposal behavior is also motivated by three further important factors: personal (Bianchi \& Birtwistle, 2012), situational (Brookshire \& Hodges, 2009) and product (Albinsson \& Parera, 2009) characteristics. These scholars believe that the combination of these characteristics and the number of ways in which to dispose of unwanted clothes are responsible for this trend.

Personal characteristics refer to mental characteristics and personal qualities that strongly govern an individual's way of life. Gunnells, Hale and Hale (2009) suggest that these characteristics are made up from psychological, demographic, and cognitive elements. In this study, the psychological components are represented by value, emotion, self-concept, and trust. Value is the guiding principle by which individuals maintain their lifestyle (Schwarz, 1992). According to Brookshire and Hodges (2009), SHC disposal behavior is primarily guided by utilitarian (functional) and hedonic (pleasurable) value. Individuals with a high utilitarian concept of value selectively choose and decide which of their clothes are unwanted according to the physical benefits or condition of the items. For example, the owner evaluates whether an item is still wearable or not. On the other hand, people with a high hedonic concept of value evaluate the items based on their sentimental/ emotional value (Fortenbaugh, 1969). That is, the more sentimental value the clothes have (i.e., a gift from grandma), the more difficult for the owner to dispose of them. To Brookshire and Hodges (2009), throwing out clothes with high sentimental value creates a sense of guilt which generates self-blame and self-hate (Baumeister, Stillwell \& Heatherton, 1994) and negative self-evaluation (Lazarus, 1991). Consequently, it affects and hurts the individual's personality (Joung, 2013) and self-concept (Albinsson \& Parera, 2009). Thus, in order to avoid this negative emotion, owners of original clothes tend to keep them (Brookshire \& Hodges, 2009).

In addition to the psychological factor, scholars note that demographic components such as age (Bianchi \& Birtwistle, 2012; and Shim, 1995), gender, and religion (Felix et al., 2013) are responsible for SHC disposal behavior. Bianchi and Birtwistle's (2012) cross-cultural study in Australia and Chile found that older people tend to dispose of their unwanted clothes through charity or recycle methods. Their findings are echoed in the US (Shim, 1995) and Ghana (Felix et al., 2013). Hoyer, MacInnis and Pieters (2013) explain this universal trend occurs due to older people tending to have higher altruism behavior. That is, older people tend to feel socially and morally responsible for helping other people in need (Shim, 1995). In different studies, females are found to be consistently more likely to dispose of their SHC (Felix et al., 2013) and discard fewer garments than males (Shim, 1995). These is because females are regarded as having more environmental awareness (Shim, 1995) than men and want to conserve the environment for future generations (Felix et al., 2013). In the same study, Felix et al. (2013) also found that although different religions have different tendencies in terms of disposing of their SHC, highly religious individuals tend to dispose of their SHC more responsibly. This is because religious people believe that conservation (saving the Earth) is their responsibility (Saraswat \& Bhadauria, 2009).

Cognitive factors, on the other hand, refer to individuals' thinking process with regard to fashion innovativeness or adaption (Bianchi \& Birtwistle, 2010). For example, an individual with high fashion innovativeness may alter and reuse their unwanted clothes and therefore show a reduction in SHC disposal behavior. Further, Bianchi and Birtwistle (2010) argue that the level to which cognitive factors affect disposal behavior depends on individual consciousness and awareness of new trends and their skills in altering their clothes.

Situation characteristics refer to a specific interaction between the original clothes owner and the specific situation at the given time (Moon \& Kim, 2001) - that is, the interaction with their economic condition (Joung \& Poaps, 2013), convenience (Brookshire \& Hodges, 2009), and changes in family and house situations (Hibbert et al., 2005). Moon and Kim (2001) argue that such situational factors lead to different disposal behavior. For example, Joung and Poaps' (2013) study of US college students noted that the higher dollar value of their SHC prompts students to recycle their clothes more often. In addition, Rucker et al. (1995) suggest that extra income is also responsible for high disposal behavior because the more income the individual earns, the more spending and therefore this individual is able to renew their closet more often. Furthermore, Domina and Koch (2001) found that hassle free access to recycling significantly improves individuals' tendency to dispose of their 
SHC. Also, Ekstrom and Salomonson (2014) note that clear and visible signage and the position of the collection bin enhances disposal behavior. Finally, Hibbert et al. (2005) document that family bereavement as well as moving homes is also responsible for improving the number of SHC that are recycled. As a result, Rucker et al. (1985) conclude that there are many reasons to improve original owners' desire to "get rid of unwanted clothes".

Product factors refer to any added value characteristics of the SHC (Van Ness \& Cramer, 2005). This includes sentimentality and memory value (Albinsson \& Perera, 2009). According to Albinsson and Perera (2009) clothes are very personal items that accompany individuals' transitions in the process of finding their self-identity. As a result, these clothes enable individuals to flash back to old memories and experience enjoyment and pleasure. Consequently, individuals tend to keep clothes with a high value of sentimentality and memory (Albinsson \& Perera, 2009). Brief additional information of SHC disposal behavior is presented in Table 2 .

\section{SHC Consumption Behavior}

Understanding the full picture of the SHC consumption phenomenon has attracted scholars since the medieval era (Han, 2013). Initially, scholars believed that the consumption of SHC was primarily dominated by buyers' financial situation (Guiot \& Roux, 2008). In reality, motivations to consume SHC are complex and are generated by different factors. These

Table 2

SHC Disposal Behavior

\begin{tabular}{|c|c|c|c|c|}
\hline Authors & & Motivation & & Findings \\
\hline $\begin{array}{l}\text { Brookshire \& } \\
\text { Hodges (2009) }\end{array}$ & Personal & Psychology & Emotion & $\begin{array}{l}\text { The study found that negative emotions, i.e. guilt, play an } \\
\text { important role in disposing of SHC. The threat of feelings } \\
\text { of guilt promotes original owners to keep their unused/ } \\
\text { unwanted clothes. }\end{array}$ \\
\hline $\begin{array}{l}\text { Albinsson \& } \\
\text { Perera (2009) }\end{array}$ & & & Self-Concept & $\begin{array}{l}\text { The authors found that individuals tend to maintain their } \\
\text { self-concept by disposing of clothes that do not fit with } \\
\text { their adopted and claimed self-identity. }\end{array}$ \\
\hline Joung (2013) & & & Personality & $\begin{array}{l}\text { The study found that materialistic individuals are more } \\
\text { likely to prefer newer styles and expensive clothes and } \\
\text { tend to get rid of their older style and inexpensive clothes. }\end{array}$ \\
\hline $\begin{array}{l}\text { Bianchi \& } \\
\text { Birtwistle (2012) }\end{array}$ & & Demography & Age & $\begin{array}{l}\text { This study found that in comparison with developing } \\
\text { countries like Chile, older people in Australia tend to have } \\
\text { higher SHC disposal behavior through charity. }\end{array}$ \\
\hline \multirow[t]{3}{*}{ Felix et al. (2013) } & & & Age & $\begin{array}{l}\text { The authors reasoned that older people tend to keep their } \\
\text { clothes for future generation rather than giving them away } \\
\text { or recycling them. }\end{array}$ \\
\hline & & & Gender & $\begin{array}{l}\text { In this study, females were found to value altruism highly } \\
\text { and therefore tend to recycle more than males. Males on } \\
\text { the other hand, are willing to recycle if they receive a profit } \\
\text { in return. }\end{array}$ \\
\hline & & & Religion & $\begin{array}{l}\text { Religious people were found to positively promote recycle } \\
\text { behavior. They are more aware of saving the environment } \\
\text { (save dustbin space). }\end{array}$ \\
\hline $\begin{array}{l}\text { Bianchi \& } \\
\text { Birtwistle (2010) }\end{array}$ & & Cognitive & $\begin{array}{l}\text { Thinking } \\
\text { process }\end{array}$ & $\begin{array}{l}\text { The study showed that the higher individual's fashion } \\
\text { awareness, the higher the tendency to reuse or alter } \\
\text { clothing or donate it to organizations that can reuse them. }\end{array}$ \\
\hline $\begin{array}{l}\text { Joung \& Poaps } \\
\text { (2001) }\end{array}$ & Situation & & Economic & $\begin{array}{l}\text { Findings indicated that individuals tend to recycle their } \\
\text { clothes to earn extra money that they can use when } \\
\text { purchasing new clothes. }\end{array}$ \\
\hline $\begin{array}{l}\text { Brookshire \& } \\
\text { Hodges (2009) }\end{array}$ & & & Convenience & $\begin{array}{l}\text { The authors noted that individual's tendency of recycling } \\
\text { SHC highly dependence on the convenience of donation } \\
\text { sites. }\end{array}$ \\
\hline $\begin{array}{l}\text { Hibbert et al. } \\
(2005)\end{array}$ & & & $\begin{array}{l}\text { Housing } \\
\text { situation }\end{array}$ & $\begin{array}{l}\text { The study revealed that among other reasons, moving } \\
\text { home and bereavement are responsible for SHC disposal } \\
\text { behavior. }\end{array}$ \\
\hline $\begin{array}{l}\text { Albinsson \& } \\
\text { Perera (2009) }\end{array}$ & Product & & Sentimentality & $\begin{array}{l}\text { The study found that clothes offer sentimental value and } \\
\text { memories. This value cherishes a specific memory that } \\
\text { produces a specific emotional state. }\end{array}$ \\
\hline
\end{tabular}


include ethical beliefs, originality, nostalgic pleasure, self-expression, social pressure, treasure hunting, and so on. These factors, according to Carvellon, Carey and Harm (2013), show that motivations to consume SHC are multifaceted and compounded by more than one factor. In general, the findings show that the motivation to consume SHC can be classified into economic (internal vs external), psychology (inner vs peer pressure), and situational components. According to Kupers and Weibler (2008), economic components refer to economic situations that govern individual spending. Parallel with today's change in economic climate, the economic components can be classified into internal and external components (Blomgren, Sattari, Peighambari \& Levihn, 2014). Internal economic components are defined as internal controllable components (i.e., income, household situation, and frugality) that affect the level of individual spending. External economic components, on the other hand, are known as uncontrollable external components (i.e., price).

With reference to internal economic components, Parsons (1999), Hossain (2005), and Na'amneh and Al Huban (2012) argue that in situations of economic hardship such as today, income can be the strongest determiner of individual consumption. They argue that economic hardship forces those individuals on lower incomes to find alternative forms of consumption to overcome the economic pressure they are experiencing. In other words, those on a lower income simply cannot afford to buy new clothes and as a result they are forced to consume SHC. In a different study, Grasso, McEnally, Widdows, and Herr (2000) suggest that this finding needs to be treated with caution. Their research noted that customers' intention to consume SHC was not purely affected by their personal income but in fact by their collective household income. To Benson (2007), this situation also suggests that household income is responsible for SHC consumption - for example, the number and gender of household members, their standard of living, and their ability to consistently fulfil their basic needs. Her study noted that the larger the number of household members, the stronger their likelihood to consume SHC.

This is because each of the household members needs to ensure that they have enough leftover funds to spend on a whole range of needs; therefore, they must avoid unaffordable spending that may further stretch tight resources and therefore choose to consume SHC. Based on these discussions, Srinivasan and Sivakumar (2011) conclude that in negative economic situations, individuals tend to be wiser in their spending. In addition to the above studies, Carvellon et al. (2013) study found that SHC consumption is also generated by frugality. As an individuals' spending control mechanism, frugality limits an individual's unnecessary spending on economic goods in order to achieve long-term goals. This limitation includes buying new clothes. To these individuals, buying new clothes is seen as a violation of economic value consciousness and more importantly, it leads to becoming materialistic and compulsive. Thus, in order to achieve their final goals, people with high frugality tend to manage and discipline their spending and always seek better ways to obtain fair deals (Roux \& Giout, 2008).

As well as internal economic components, scholars argue that external economic components (i.e., price) are also responsible for $\mathrm{SCH}$ consumption (Grosso et al., 2000). Grosso et al. (2000) argue that in conjunction with income, price intensifies the tendency of individuals to purchase SHC. To Roux and Giout (2008), lower priced SHC represents an economic value, psychological satisfaction, and power dimensions. For individuals, the economic value of SHC not only offers fairness but more importantly it provides an opportunity to gain a bargain which results in price gratification (Guiot \& Roux, 2010). Price gratification is also known as a satisfaction with the ability to manage spending ( $\mathrm{Xu}$ et al., 2014), which helps individuals to experience financial profit and a smart shopping experience, which in turn generate a higher sense of economic value for their money (Xu et al., 2014).

The second motivation of SHC is psychological factors which refer to the strong driving force that is generated from intrinsic and extrinsic factors (Fuster et al., 2012). In relation to SHC intrinsic factors include morals, image, value, materialism, and nostalgia, whereas extrinsic factors include uniqueness, authenticity and originality, and peer pressure.

Clammer (1992) argues that shopping and consuming are highly related and directly affected by psychological factors. Thus, the consumption of SHC represents an individual's commitment to SHC and more importantly the wearer's self-identity. Such identity, according to Rothstein (2005), is affected by individuals' specific circumstances at a given time and becomes an important structural condition that determines their consumption of SHC. To illustrate, Braze-Govan and Binay's (2010) study on Australian's disposed goods consumption revealed that their respondents tangibilized their moral identity through anti-consumerism and recommodified disposed clothes by buying their SHC at charity organizations. On the other hand, Roux and Giout (2008) suggest that individuals also take an advantage of the low 
price of SHC as their platform to enrich their clothing collections. In other words, consuming SHC allows them to have more clothes which in turn satisfies their materialist needs.

According to scholars, different self-identities show that individuals employ different values as fundamental factors to make decisions (Jagel et al., 2012) and deal with different circumstances (Isla, 2013). For example, moral identity is generated when individuals exercise their ethical and altruism values whereas materialism is promoted by economic and hedonic values. To add to this complexity, Xu et al. (2014) argue that individuals are also influenced by environmental and symbolic values. Further, the authors suggest that the selection of these values is determined by individuals' culture. Thus, Isla (2013) concludes that the consumption of SHC is a genuine representation of wearers' identity and values. Interestingly, Roux and Giout (2008) also found that the motivation to consume SHC is created by a degree of nostalgia for SHC. To Zauberman, Ratner, and Kim (2009), nostalgia is the propensity of individuals to flashback to personal experiences and values of the past. These authors argue that in the context of SHC, nostalgia is a social emotion that reminds individuals of their selfidentity and more importantly to their past interaction with others. For example, SHC may remind them of special events such as graduations, puberty etc. Sedikides, Wildschut and Baden (2004) suggest that by consuming SHC for the sake of nostalgia, individuals re-connect and strengthen their symbolic interaction with others. Thus, Roux and Giout (2008) conclude that nostalgia is one of the most important ingredients in the consumption of SHC.

In addition, the study also found that SHC consumption is also heavily affected by extrinsic motivations such as peer pressure (Xu et al., 2014), authenticity (McColl, Canning, McBridge, Nobbs, and Shearer, 2013), uniqueness, and exclusivity (Braze-Govan \& Binay, 2010). The Theory of Reason Action holds that social pressure or peer pressure is responsible for determining SHC consumption behavior (Ajzen \& Fishbein, 1980) and becomes a reference for individuals to conduct their behavior (Xu et al., 2014). Failure to follow such references are seen as a failure to comply with approved behavior (Armitage \& Conner, 2001) which promotes a rejection from the group (Pohja, 2010). In the context of SHC, consuming SHC is seen as a socialization process or a confirmation of social norms which helps individuals to understand the acceptable values and reduce negative concerns from society (Xu et al., 2014).
Despite pressures to follow society's beliefs, individuals still tend to maintain their own identity by purchasing unique (Braze-Govan \& Binay, 2010; Roux \& Giout, 2008), exclusive (Beard, 2008), and authentic (Guiot \& Roux, 2010; McColl et al., 2013) SHC products. For example, Hansen's (2000) study in Zambia found that SHC customers see uniqueness in SHC in that it helps wearers to stand out among the crowd and receive more attention which determines their existing and future interaction with others. In a different study, Beard (2008) also found that unique SHC is perceived as a premium and claimed as an important vintage item. The premium SHC item is very limited and because of this high degree of rareness, the wearer of a unique SHC item is considered as an individual with a high fashion sense (Quayson, 2010) which further promotes a high level of selfconfidence (Hansen, 2000). To McColl et al. (2013), the exclusivity of SHC is inseparable from the authenticity or originality of SHC. They believe that originality not only provides economic value but more importantly, it offers a high historical value which allows wearers to take part in history. Thus, based on the explanation above, McColl et al. (2013) conclude that individuals see SHC as a life treasure. More information is presented in Table 3. Situational factors are regarded as the next major determinant of SHC purchasing behavior. In this study, situational factors consist of customers, sellers, and general dimensions.

The customer dimension refers to any situational factors (i.e., culture, past purchases, and a distance from the social system) that are directly related and affect individuals' belief in purchasing SHC. The cultural dimension is closely associated with individuals' cultural and ethnic ideology that governs their SHC purchases (Smirchich, 1983). According to Na'amneh and Al Husban (2012), the cultural dimension has been contaminated by globalization and as a consequence, it has blurred conventional socio-cultural identity and driven individuals to accept and tolerate new purchasing behavior as their new identity. In order to maintain this new identity, individuals race to adopt cross-cultural consumption through purchasing SHC items. For example, Hansen's (1999) study found that Gambians prefer to wear Western style clothes rather than their traditional clothes due to their functionality and image and because of a trend. This trend, according to $\mathrm{Xu}$ et al. (2014), is also strengthened by individuals' past experience of consuming SHC. In their study, Xu and her colleagues found that the process of purchasing SHC allows individuals to reflect adventure-seeking and gambling characteristics. That is, individuals are dri- 
Table 3

Intrinsic and Extrinsic SHC Psychological Motivation

\begin{tabular}{|c|c|c|c|}
\hline Authors & Intrinsic & Extrinsic & Findings \\
\hline $\begin{array}{l}\text { Braze-Govan \& } \\
\text { Binay (2010) }\end{array}$ & \multicolumn{2}{|l|}{ Morals } & $\begin{array}{l}\text { Customers buy SHC products to informally address their } \\
\text { individualized moral identity as the expression of their social life. }\end{array}$ \\
\hline $\begin{array}{l}\text { Na'amneh \& Al } \\
\text { Huban (2012) }\end{array}$ & \multicolumn{2}{|l|}{ Image } & $\begin{array}{l}\text { Customers buy SHC products to maintain and improve their self- } \\
\text { image which is produced by SHC price, authenticity, quality, brand, } \\
\text { and westernness. }\end{array}$ \\
\hline Xu et al. (2014) & \multicolumn{2}{|l|}{ Values } & $\begin{array}{l}\text { Customers' intention to buy SHC is highly determined by their } \\
\text { culturally perceived values. }\end{array}$ \\
\hline Isla (2013) & \multicolumn{2}{|l|}{ Values } & $\begin{array}{l}\text { The SHC purchasing behavior of Filipino customers is affected by } \\
\text { functionality value. }\end{array}$ \\
\hline Jagel et al. (2012) & \multicolumn{2}{|l|}{ Values } & $\begin{array}{l}\text { Economic value, image, personal well-being, ethical concerns, and } \\
\text { altruism are responsible for SHC consumption. }\end{array}$ \\
\hline \multicolumn{3}{|c|}{ Roux \& Giout (2008) Materialism } & $\begin{array}{l}\text { Higher materialism drives individuals to buy SHC in order to both } \\
\text { save money and buy more products. }\end{array}$ \\
\hline \multicolumn{3}{|c|}{ Roux \& Giout (2008) Nostalgia } & $\begin{array}{l}\text { Nostalgia is considered as recreational motivation to buy SHC due } \\
\text { to its ability to allow customers to flashback to past memories and } \\
\text { experiences. }\end{array}$ \\
\hline \multicolumn{2}{|l|}{$\begin{array}{l}\text { Braze-Govan \& } \\
\text { Binay (2010) }\end{array}$} & Uniqueness & $\begin{array}{l}\text { The degree of SHC uniqueness allows individuals to express their } \\
\text { identity, feelings, and morality in terms of their consumption. }\end{array}$ \\
\hline \multicolumn{2}{|c|}{ Roux \& Giout (2008) } & Uniqueness & $\begin{array}{l}\text { In addition to unique designs, SHC has the ability to provide and } \\
\text { fulfil the need for uniqueness and therefore motivates individuals to } \\
\text { consume SHC. }\end{array}$ \\
\hline \multicolumn{2}{|l|}{$\overline{\text { Hansen (1999) }}$} & Uniqueness & $\begin{array}{l}\text { SHC provides an individual with the opportunity to show off their } \\
\text { expression of variety, individuality, and uniqueness in their clothing } \\
\text { practice. }\end{array}$ \\
\hline \multicolumn{2}{|l|}{ Hansen (2000) } & Uniqueness & $\begin{array}{l}\text { Despite economic pressure, SHC allows individuals to look } \\
\text { outstanding and exclusive. }\end{array}$ \\
\hline \multicolumn{2}{|c|}{ Guiot \& Roux (2010) } & Authenticity & $\begin{array}{l}\text { The authentic character of SHC helps individuals to express their } \\
\text { individuality. }\end{array}$ \\
\hline \multicolumn{2}{|c|}{ McColl et al. (2013) } & Authenticity & $\begin{array}{l}\text { The story behind SHC reflects its authenticity and allows } \\
\text { individuals to take part in history. }\end{array}$ \\
\hline \multicolumn{2}{|l|}{ Xu et al. (2014) } & Social Norms & $\begin{array}{l}\text { Social norms facilitate customers' SHC purchasing behavior and } \\
\text { socialization process to ensure group memberships. }\end{array}$ \\
\hline
\end{tabular}

ven to find their luck and enjoy the treasure hunting experience of seeking for SHC. To illustrate, individuals may visit many thrift shops or other outlets to find a rare and good quality vintage SHC item and this process enhances their adrenalin and offers a different type of experience and satisfaction.

In addition to this new excitement, at the same time, individuals also are perceived as ethical individuals (Guiot \& Roux, 2010). Because of these positive experiences, therefore, it is reasonable to say that past experience plays a significant role in affecting SHC purchase intention. In a different study, Guiot and Roux (2010) noted that SHC consumption is also a form of public protest towards individuals' dissatisfaction with the current clothes purchasing system. This dissatisfaction encourages individuals to distance themselves from buying new clothes and instead purchasing SHC items. According to Guiot and Roux, this attitude allows individuals to take revenge and at the same time escape the costs of adding new clothes to their collection. To these individuals, buying new clothes is perceived as irresponsible behavior as they believe that buying new clothes is a waste of resources and a sign of rampant consumerism. Thus, such individuals are more likely to purchase SHC.

In addition to the consumer dimension, it was found that sellers are also responsible for increasing SHC consumption. McColl et al. (2013) study on SHC retailing found that the recent re-imaging of thrift shops has improved customer visitation and more importantly increased the shops' turnover and profitability. These authors reasoned that this new positioning requires sellers to be fully equipped with knowledge of SHC and to provide high level of customer service with innovative trading formats (i.e., attractive window displays, store environments, and personality). In addition, Hansen (2000) found that SHC sellers are also required to act as good models by looking elegant and presentable in order to exhibit 
their SHC and more importantly to be more agile in finding their suppliers. The combination of these factors are believed to improve the attractiveness of SHC items (Hansen, 2000).

Finally, the general dimension of SHC consumption is closely related to environmental awareness (Grasso et al., 2000) the degree of Westernization (Hansen, 1999), and modernization (Besnier, 2004). Today, consumers are more critical of what they buy and consume. In other words, modern customers are more environmentally mindful and accordingly, they tend to save the world by purchasing recycled goods such as SHC (Grasso et al., 2000). To such individuals, purchasing SHC offers dual benefits: economic and environmental. In term of economic benefits, Grasso et al. (2000) argue that individuals can save their money, whereas in relation to the environmental benefits, individuals are "saving the world" by reducing waste through remodifying and refunctioning SHC, and more importantly, by eliminating the unnecessary toxic and harmful substances (i.e., coloring, cloth waste, etc.) created in the production of new clothes. Individuals, therefore, tend to buy SHC to experience these dual benefits. In addition to environmental awareness, Hansen (1999) and Besnier (2004) note that the level of Westernization or modernization is also responsible for the SHC consumption trend. Ansori (2009) argues that in today's era of globalization, developing countries around the world are attempting to improve their economies through modernization. According to Besnier (2004), modernization has pressurized the local people into adopting a more Western life style including Western type clothes. Hansen (1999) found that in Zambia Western clothes are not only perceived as a symbol of modernization but also function as a symbol of equality. By wearing Western SHC clothes, the wearers not only feel good about themselves but they also feel more freedom from existing local and cultural constraints. Brief information is presented in Table 4.

\section{The Impacts of SHC Consumption Behavior}

SHC consumption is unstoppable and as a result of this worldwide trend, SHC has changed the clothing purchasing landscape significantly. Scholars believe that SHC consumption has positive (Haggblade, 1990) impacts on society. Haggblade (1990) argues that SHC positively contributes to the local economy through improving the local employment rate. In his comparative study of several developing African countries, the author found that SHC enhances local income through establishing different type of employments. This includes the sorting out and grading of SHC, selling SHC as a street vendor (Hansen, 2004), or being a distributor for SHC (Haggblade, 1990). To Hansen (2004), such new job opportunities help individuals to improve their career, offer an alternative income and new skills, and also contribute to the development of their country by paying tax. Hansen (1999) also notes that SHC triggers creativity.

SHC are initially imported from a source country in their original sizes, colors, condition, and styles. These characteristics not only provide a high degree of uniqueness, but also challenge potential buyers. For example, the condition of some SHC may mean that items are no longer usable or the size is inappropriate etc. This situation encourages SHC vendors and buyers to modify SHC either to make items fit or to be used for a different function entirely (i.e., handbag, wall accessories etc.) (Haggblade, 1990). These new resized or modified items improve their attractiveness and salability without abandoning their $100 \%$ originality and characteristics. In other words, the creativity of SHC vendors and buyers provides a clothing alternative to their buyers (Haggblade, 1990) and at the same time, these buyers can still experience good quality products which they feel will improve their clothing standard (Hansen, 1999) within an affordable budget.

However, SHC also has a negative impact (Brooks \& Simon, 2012) and its consumption has received criticism. For example, Hansen's (2000) study in African countries found that the SHC industry has negatively affected local clothing industries. Governments in these countries hold that the local clothing industry cannot compete with SHC's lower price and higher quality. To these administrations, the entry of SHC has created unfair competition. They believe that local industry has very limited technology, skills, and brand awareness, whereas SHC represents branded clothing that is produced by giant clothing companies that have technology and skills. Because of this unfairness, the administrations in many less developed countries have called for a ban on SHC products to protect the local clothing industries (Hansen, 2004).

With the explosion of SHC products in the market, Besnier (2004) also notes that this trend not only directly affects the manufacturers, but it also negatively affects local clothes sales significantly. Existing shop owners regard SHC as hijacking their business. To these owners, SHC products enter the market unfairly; that is, they are brought into the country as personal effects (Besnier, 2004) or smuggled (Isla, 2013) and therefore they are not subject to taxation. Consequently, SHC vendors can price their items more affordably, in contrast to existing clothes 
Table 4

Three Dimensions of Situational Factor of SHC Purchasing Trend

\begin{tabular}{|c|c|c|c|}
\hline Authors & Dimension & Factors & Findings \\
\hline $\begin{array}{l}\text { Na'amneh \& Al } \\
\text { Huban (2012) }\end{array}$ & Customer & Culture & $\begin{array}{l}\text { The study shows that individuals purchase SHC according to their } \\
\text { own desires, knowledge, and interests, as they impose their own } \\
\text { cultural systems of values and practices on these commodities. }\end{array}$ \\
\hline Hansen (1999) & & & $\begin{array}{l}\text { In Third World countries, individuals appear to consume SHC by } \\
\text { compromising their cultural beliefs and historical background. }\end{array}$ \\
\hline Xu et al. (2014) & & Past experience & $\begin{array}{l}\text { The study found that past experience of SHC consumption } \\
\text { determines customers' desire to purchase further SHC. }\end{array}$ \\
\hline $\begin{array}{l}\text { Guiot and Roux } \\
\text { (2010) }\end{array}$ & & $\begin{array}{l}\text { Distance to a current } \\
\text { system }\end{array}$ & $\begin{array}{l}\text { According to these authors, purchasing SHC allows individuals to } \\
\text { take revenge and at the same time escape the costs of buying new } \\
\text { clothes to add to their clothes collection and possessions. }\end{array}$ \\
\hline $\begin{array}{l}\text { McColl } \\
\text { et al. (2013) }\end{array}$ & Seller & Positioning & $\begin{array}{l}\text { SHC retail re-imaging strategy shows that the recent positioning of } \\
\text { thrift shops has increased customer visitations. }\end{array}$ \\
\hline $\begin{array}{l}\text { Grasso } \\
\text { et al. }(2000)\end{array}$ & General & $\begin{array}{l}\text { Environmental } \\
\text { awareness }\end{array}$ & $\begin{array}{l}\text { Modern customers are more environmentally mindful and } \\
\text { accordingly, they tend to save the world by purchasing recycled } \\
\text { goods such as SHC. }\end{array}$ \\
\hline Besnier (2004) & & Modernization & $\begin{array}{l}\text { Modernization has pressurized the local people of Third World } \\
\text { countries to adopt a more Western life style including Western type } \\
\text { clothes. }\end{array}$ \\
\hline Hansen (1999) & & Westernization & $\begin{array}{l}\text { Western SHC is not only perceived as a symbol of modernization } \\
\text { but also functions as a symbol of equality. }\end{array}$ \\
\hline
\end{tabular}

Table 5

Quick Comparison of Advantages vs Disadvantages of SHC

\begin{tabular}{llll}
\hline \multicolumn{3}{c}{ Advantages vs. Disadvantages of SHC on Society } & \\
\hline Advantages & Authors & Disadvantages & Authors \\
\hline Employment & Haggblade (1990); Hansen (1999) & Reduce sales & Besnier (2004) \\
\hline Creativity & Hansen (1999) & Kills local industry & Brooks \& Smith (2012) \\
\hline Clothing alternative & Haggblade (1990) & & \\
\hline Clothing standard & Hansen (1999) & & \\
\hline
\end{tabular}

shop owners who need to consider tax on the price of the clothes they sell. Because of this situation, Haggblade (1990) regards the SHC trend as a politically sensitive issue and the industry should be highly regulated to protect local clothing industries.

\section{Future Research}

\section{What We Don't Know About SHC}

The discussion above showed that scholars have extensively investigated the SHC trend. From their significant efforts, an understanding emerged that SHC is a complex phenomenon and previous scholars have revealed important components of this trend. Although the preceding discussion offered a good understanding of the history, consumption, and disposal of SHC and the impact of SHC on society, there are clearly many questions that still need to be answered. Therefore, based on the discussion, a list of future directions that scholars need to consider is provided below. The intensive investigation of this study has shown that the extant literature on the SHC phenomenon has been built based on consumers' perspective and as far as the authors' best knowledge; there has been limited research on the sellers' perspective. Therefore, the first recommendation is to fill this gap. For example, why and what makes individuals sell SHC? What are the advantages and disadvantages of selling SHC products? How do SHC sellers choose their strategy to sell their goods in comparison to new clothes sellers? Is there any differences in selling to high end customers as opposed to ordinary customers? If so, what are they? In addition to the above questions, it is suggested that the SHC investigation be taken to another place. So far, SHC investigations have mainly been conducted in either African countries and/or in well-developed countries such as the US, Europe and Australia. Although the findings from these continents may provide a general picture of the SHC phenomenon, the authors believe that future scholars need to expand their investigations to Asia, the many emer- 
ging countries, and newly developed countries. The findings from these continents may provide different perspectives and findings that may be able to more comprehensively address the phenomenon.

The third suggestion is to involve more heterogeneous samples. So far, the extant literature has largely employed and interviewed low and mid-end participants and to the best of the authors' knowledge, there has been no study that involves the high-end segment as study participants. Again, understanding different segments will provide a full picture and understanding of the antecedents of why people purchase and wear SHC.

Next, it is suggested that future scholars also look at the different motivations of purchasing SHC. These include 1) political motivation - for example, the degree of direct and indirect corruption, government regulations, etc.; 2), product motivation - for example, the degree of direct and indirect advertising, type of advertising, and non-branded SHC; and finally 3 ), product motivation - for example, the material of SHC items etc.

Finally, it is suggested that future researchers allocate efforts into determining the impact of SHC on future generations. For example, what is the impact of adult SHC consumption on their children's future SHC purchasing behavior, perceptions, and intentions?

\section{Limitations}

Like any meta-analysis research, this study has several limitations. This research was carried out based on 131 content analyses. Although the literature enabled an understanding of the SHC phenomenon, it was not entirely adequate to provide an understanding of the entire phenomena of SHC. Therefore, this literature may not represent the whole phenomenon. Findings from this research also drew from literature that was published between 1990 and 2014. Although the research time frame covered nearly 25 years, it did not include 2015. Therefore, some of the newest findings were not included and portrayed in this study. Finally, the research did not include literature from books, book chapters, proceedings, working papers, and dissertations. The inclusion of these may have added a different perspective on the SHC phenomenon.

\section{Conclusion}

"The SHC sector has grown into an important economic factor which provides a living for more than a hundred thousand people. Added to this is the fact that second hand clothes enjoy a high degree of acceptance in many countries and among all social strata" (Baden \& Barber, 2005). The above quotation clearly shows that SHC consumption has taken off and can no longer be categorized as an alternative business. The literature shows that a worldwide SHC trend has evolved and changed over time and deserves a full investigation. Within this study, it was found that scholars have concentrated their studies on three important sectors: a history of SHC, consumption and disposal of SHC, and the impact of SHC. Although these dimensions have provided good leads and some understanding, the findings from these studies do not offer a full picture of the SHC phenomenon. This study is among the first to screen and content analyze the SHC literature. The findings of this study provide clarity on what is known about this phenomenon and more importantly they provide clear future research directions. As the SHC consumption trend continues to grow, a strong body of research is urgently needed to provide local governments and business practitioners with guidance in handling this phenomenon.

\section{References}

Abimola, O. (2012). The international trade in second hand clothing: Managing information asymmetry between West African and British traders. Textile, 10(2), 184-199.

Ajzen, I. \& Fishbein, M. (1980). Understanding attitudes and predicting social behavior. Englewood Cliffs, NJ: Prentice Hall.

Albinsson, P. A. \& Perera, Y. (2009). From trash to treasure and beyond: The meaning of voluntary disposition. Journal of Consumer Behavior, 8, 340-353.

Ansori, M. H. (2009). Consumerism and the emergence of a new middle class in globalizing Indonesia. Explorations: A Graduate Student Journal of Southeast Asian Studies, 9(Spring), 87-97.

Apatoff, A. (2014). Shailene woodley: I only wear used clothes unless it's for work. Available at http://stylenews.peoplestylewatch.com/2014/03/ 05/shailene-woodley-divergent-used-clothes-red -carpet/.

Armitage, C. J. \& Conner, M. (2001). Efficacy of the theory of planned behavior: A meta analytic review. British Journal of Social Psychology, 40, 471-499.

Baden, S. \& Barber, C. (2005). The impact of the second-hand clothing trade on developing countries. GB: Oxfam.

Barahona, V. L. \& Sanchez, J. N. (2012). Dressing the poor: The provision of clothing among the 
lower classes in eighteen century Madrid. Textile History, 43(1), 23-42.

Baumeister, R. F., Stillwell, A. M., \& Heatherton, T. F. (1994). Guilt: An interpersonal approach. Psychological Bulletin, 115(2), 243-267.

Beard, N. D. (2008). The branding of ethical fashion and the consumer: A luxury niche or mass market reality? Fashion Theory, 12(4), 447-468.

Benson, S. P. (2007). What goes round comes round: Second hand clothing, furniture, and tools in working class lives in the interwar United States. Journal of Women's History, 9(1), 17-31.

Besnier, N. (2004). Consumption and cosmopolitanism: Practicing, modernity at the second hand marketplace in Nuku'alofa, Tonga. Anthropological Quarterly, 77(1), 7-45.

Bianchi, C. \& Birtwistle, G. (2010) Sell, give away, or donate: An exploratory study of fashion clothing disposal behaviour in two countries. The International Review of Retail, Distribution and Consumer Research, 20(3), 353-368.

(2012). Consumer clothing disposal behaviour: A comparative study. International Journal of Consumer Studies, 36, 325-341.

Birtwistle, G. \& Moore, C. M. (2007). Fashion clothing - where does it all end up? International Journal of Retail \& Distribution Management, 35(3), 210-216.

Blank, M. J. (2015). Young people must know their own history. Available at http://www.huffingtonpost.com/martin-j-blank/young-people-mustknow-th_b_6489738.html.

Blomgren, H., Sattari, S., Peighambari, K., \& Levihn, F. (2014). The strategy agenda of corporate Europe: Sustainability or not? In The Sustainable Global Marketplace. Berlin: Springer International Publishing, pp. 307-309.

Braze-Govan, J. \& Binay, I. (2010). Consumption of disposed goods for moral identities: A nexus of organization, place, things and consumers. Journal of Consumer Behavior, 9, 69-82.

Brooks, A. (2012). Riches from rags or persistent poverty? The working lives of second hand clothing vendors in Maputo, Mozambique. Textile, 10(2), 22-237.

Brooks, A. \& Simon, D. (2012). Unravelling the relationships between used-clothing imports and the decline of African clothing industries. Development and Change, 43(6), 1265-1290.

Brookshire, J.E.H. \& Hodges, N. N. (2009). Socially responsible consumer behavior? Exploring used clothing donation behavior. Clothing \& Textiles Research Journal, 27(3), 179-196.
Business 2 Community (2015). 30 Shocking figures and facts in global textile and apparel industry. Available at http://www.business2community. com/fashion-beauty/30-shocking-figures-factsglobal-textile-apparel-industry-01222057.

Carvellon, M.C., Carey, L., \& Harms, T. (2013). Something old, something used: Determinants of women's purchase of vintage fashion vs second hand fashion. International Journal of Retail \& Distribution Management, 40(12), 956-974.

Castillo, R.A. (2014). Second hand clothing commerce and the mobility cultural configuration: A journey to manhood crossings. Journal of Migration \& Culture, 5(2/3), 303-316.

Charbonneau, J. S. (2008). Social responsibility and women's acquisition of second hand clothing (Unpublished Doctoral Dissertation) Colorado State University, Colorado, USA.

Charpy, M. (2008). The scope and structure of the nineteenth century second hand trade in the Parisian clothes market. In. L. Fontaine (Ed.). Alternative exchanges: Second hand circulations from the sixteenth century to the present. USA: Berghahn Books.

Clammer, J. (1992). Aesthetics of the self: Shopping and social being in modern urban Japan. In R. Shields (Ed.). Lifestyle shopping: The subject of consumption. London: Routledge, pp. 197-217.

De Klerk, H. M. \& Tselepis, T. (2007). The early adolescent female clothing consumer: Expectations, evaluation and satisfaction with fit as part of the appreciation of clothing quality. Journal of Fashion Marketing and Management: An International Journal, 11(3), 413-428.

Domina, T. \& Koch, K. (2001). Textile recycling, convenience and the older adult. Journal of Family and Consumer Sciences, 93(5), 35-40.

Ekstrom, K. M. \& Salomonson, N. (2014). Reuse and recycling of clothing and textiles - a network approach. Journal of Macromarketing, April, 117

Farrant, L., Olsen, S. I., \& Wangel, A. (2011). Environmental benefits from reusing clothes. International Journal of Life Cycle Assess, 15, 726736.

Felix, A. T., Asuamah, S. Y., \& Darkwa, B. (2013). Are demographic variables determinants of recycling behaviour in Ghana? International Journal of Innovative Research \& Development, 2(7), 381-387.

Fortenbaugh, W. W. (1969). Aristotle: Emotion and moral virtue. Arethusa, 2(2), 163-185. 
Fuster, H., Iberst, U., Griffiths, M., Carbonell, X., Chamarro, A., \& Talarn, A. (2012). Psychological motivation in online role playing games: $\mathrm{A}$ study of Spanish world of warcraft players. Anales de Psicologia, 28(1), 274-280.

Gaur, S., Herjanto, H., \& Makkar, M. (2014). Review of emotions research in marketing, 2002-2013. Journal of Retailing and Consumer Service 21, 917-923.

Ginsburg, M. (1980). Rags to riches: The secondhand clothes trade 1700-1978. Costume, 14(1), 121-135.

Grasso, M. M., McEnally, M., Widdows, R., \& Herr, D. G. (2000). Consumer behavior toward recycled textile products. The Journal of the Textile Institute, 91(2), 94-106.

Guiot D. \& Roux, D. (2008). Measuring second hand shopping motives, antecedents and consequences. Recherche et Applications en Marketing, 23(4), 63-94.

(2010). A Second hand shoppers' motivation scale: Antecedents, consequences, and implications for retailers. Journal of Retailing, 86(4), 355-371.

Gunnells, K., Hale, J. E., \& Hale, D. P. (2009). Revisiting knowledge, skills and abilities needed for development and delivery project staff. SAIS 2006 Proceedings. Paper 38.

Ha-Brookshire, J. E. H. \& Hodges, N. N. (2009). Socially responsible consumer behavior? Exploring used clothing donation behavior. Clothing and Textiles Research Journal, 27(3), 179-196.

Haggblade, S. (1990). The flip side of fashion: Used clothing exports to the third world. The Journal of Development Studies, 26(3), 505-521.

Han, J. (2013). Understanding second-hand retailing: A resource based perspective of best practices leading to business success (unpublished doctoral thesis). Iowa State University, USA.

Hansen, K. T. (1999). Second hand clothing encounters in Zambia: Global discourses, western commodities and local history. Journal of the International Africa Institute, 69(3), 343365 .

(2000). Other people's clothes? The international second-hand clothing trade and dress practices in Zambia. Fashion Theory, 4(3), 245-274.

-- (2004). Helping or hindering? Controversies around the international second hand clothing trade. Anthropology Today, 20(4), 3-9.

Hibbert, S. A., Horne, S., \& Tagg, S. (2005). Charity retailers in competition for merchandise:
Examining how consumers dispose of used goods. Journal of Business Research, 58, 819828.

Holsti, O. R. (1969). Content analysis for the social science and humanities. Reading, MA: AddisonWesley.

Hossain, S. (2005). Poverty, hosehold strategies and coping with urban life: Examining "livelihood framework" in Dhaka City, Bangladesh. Bangladesh e-Journal of Sociology, 2(1), 45-52.

Hoyer, W.D., MacInnis, D. J., \& Pieters, R. (2013). Consumer behavior $\left(6^{\text {th }}\right.$ ed.), USA: South-Western Cengage Learning.

Huck, C. (2003). Clothes make the Irish: Irish dressing and the question of identity. Irish Studies Review, 11(3), 273-284.

Huffpost (2013). Woman vows to wear only second hand clothes for one year. Available at http:// www.Huffingtonpost.ca/2013/09/03/woman-wear s-secondhand-clothes-one-year_n_3861782.html

Isla, V. L. (2013). Investigating second-hand fashion trade and consumption in the Philippines: Expanding existing discourses. Journal of Consumer Culture, 13(3), 221-240.

Jagel, T., Keeling, K., Reppel, A., \& Gruber, T. (2012). Individual values and motivational complexities in ethical clothing consumption: A means-end approach. Journal of Marketing Management, 28(3/4), 373-396.

Joung, H. M. (2013). Materialism and clothing postpurchase behavior. Journal of Consumer Marketing, 30(6), 530-537.

Joung, H. M. \& Poaps, H. P. (2013). Factors motivating and influencing clothing disposal behavior. International Journal of Consumer Studies, 37, 105-111.

Jucso, P. (2008). Google scholar revisited. Online Information Review, 32(1), 102-114.

Kang, J.Y.M., Kim, K.P. J., \& Kim, J. (2013). Clothing functions and use of clothing to alter mood. International Journal of Fashion Design, Technology and Education, 6(1), 43-52.

Kressmann, F. Sirgy, J. M., Herrmann, A., Huber, F., Huber, S., \& Lee, D. J. (2006). Direct and indirect effects of self-image congruence on brand loyalty. Journal of Business Research, 59, 955-964.

Kupers, W. \& Weibler, J. (2008). Inter-leadership: Why and how should we think of leadership and followership integrally? Leadership, 4(4), 443475.

Lambert, M. (2004). Cast off wearing apparel: The consumption and distribution of second hand 
clothing in Northern England during the long eighteen century. Costume, 35(1), 1-26.

(2014). Death and memory: Clothing bequests in English Wills 1650-1830. Costume, $48(1), 46-59$.

Lastovicka, J. \& Fernandez, F. V. (2005). Three paths to disposition: The movement of meaningful possessions to strangers. Journal of Consumer Research, 31 (March), 813-823.

Lazarus, R. S. (1991). Cognition and motivation in emotion. American Psychologist, 46(4), 352367.

Lemire, B. (2006). The second hand clothing trade in Europe and beyond: Stages of development and enterprise in a changing material world, c16001850. Textile, 10(2), 144-163.

Linacre, S. (2013). Writing for publication. Auckland Institute of Technology. (11-12 February 2013).

$\mathrm{Lu}$, S. (2015). Global trade of used clothing. Available at: https://shenglufashion.wordpress. com/2015/09/30/ global-trade-of-used-clothing/.

McColl, J., Canning, C., McBridge, L., Nobbs, K., \& Shearer, L. (2013). It's vintage darling! An exploration of vintage fashion retailing. The Journal of the Textile Institute, 104(2), 140-150.

Mhango, M. W. \& Niehm, L. S. (2005). The second hand clothing distribution channel. Opportunities for retail entrepreneurs in Malawi. Journal of Fashion Marketing and Management, 9(3), 342-356.

Milgram, L. B. (2012). Reconfiguring margins: Second hand clothing and street vending in the Philippines. Textile, 19(2), 200-221.

Mintel (2009). Ethical clothing- UK 2009. London: Mintel.

Moon, J. W. \& Kim, Y. G. (2001). Extending the TAM for a world wide web context. Information \& Management, 38, 217-230.

Na'amneh, N. M. \& Al Huban, A. K. (2012). Identity in old clothes: The socio-cultural dynamics of second-hand clothing in Irbid, Jordan. Social Identities, 18(5), 609-621.

Noon, D. J. (2011). Changing patterns of consumerism: The rise and rise of the second hand. (Unpublished master's thesis). Massey University, New Zealand.

Noruzi, A. (2005). Google scholar: The new generation of citation indexes. Libri, 55, 170-180.

Ohno, T. (2011). Creating a used clothing recycling system in Japan. Available at: http://www. japanfs.org/en/news/archives/news_id030982. html.

Parsons, L. (1999). New goods, old records and second-hand suits: Charity shopping in SouthWest England. International Journal of Nonprofits and Voluntary Sector Marketing, 5(2), 141-151.
Pohja, T. L. (2010). Searching for a definition of social norms: An analysis of 690 journal articles. Paper was presented at ICSB World Conference Proceedings: 1-17 Washington.

Quayson, A. (2010). Signs of the times: Discourse ecologies and street life on Oxford St., Accra. City\& Society, 22(1), 72-96.

Rahman, O., Jian, Y., \& Liu, W. S. (2010). Evaluative criteria of denim jeans: A cross national study of functional and aesthetic aspects. The Design Journal, 13(3), 291-311.

Rothstein, F. A. (2005). Challenging consumption theory: Production and consumption in Central Mexico. Critique of Anthropology, 25(3), 279306.

Roux, D. \& Guiot, D. (2008). Measuring second hand shopping motives, antecedents and consequences. Recherche et Applications en Marketing, 23(4), 63-94.

Rucker, M., McGee, K., Alves, B., Hopkins, M., Sypolt, T., \& Watada, M. (1995). Factors influencing consumer initiation of second hand markets. European Advances in Consumer Research, 2, 425-429.

Saraswat, V. \& Bhadauria, V.P.S. (2009). Intellectual property \& human environment: Towards a sustainable future. Conference: Recent Advances in Environmental Protection at Agra.

Schwarz, S. H. (1992). Universals in the content and structure of values: Theoretical advances and empirical tests in 20 countries. In M. Zanna (Ed.), Advances in Experimental Social Psychology, 25, pp. 1-65. New York: Academic Press.

Sedikides, C., Wildschut, T., \& Baden, D. (2004). Nostalgia: Conceptual issues and existential functions. In J. Greenberg, S. Koole and T. Pyszczynski. (eds.). Handbook of Experimental Existential Psychology (pp. 200-214). New York, NY: Guilford Press.

Shim, S. (1995). Environmentalism and consumers' clothing disposal patterns: An exploratory study. Clothing \& Textiles Research Journal, 13(1), 38-48.

Slotterback, J. N. (2007). Threadbare: The used clothing trade and its effects on the textile industries in Nigeria and Other Sub-Saharan African Nations. Available at http://www. docstoc.com/docs/89480354/ threadbare-theused-clothing-trade-and-itseffects-on-the-textile.

Smirchich, L. (1983). Concepts of culture and organizational analysis. Administrative Science Quarterly, 28(3), 339-358.

Smitha, F. E. (2015). Plague and progress I the 1300s - macro history and world timeline. Available at http://www .fsmitha.com/h3/h14eu1.htm. 
Sontag, M. S. \& Lee, J. (2004). Proximity of clothing to self-scale. Clothing and Textiles Research Journal, 22(4), 161-177.

Srinivasan, S. R. \& Sivakumar, S. N. V. (2011). Strategies for retailers during recession. Journal of Business and Retail Management Research, 5(2), 94-104.

Stearns, P. N. (2013). Why study history Available at https://www.historians.org/about-aha-and-membership/aha-history-and-archives/archives/whystudy-history-(1998).

Steinbring, Y. \& Rucker, M. (2003). Utilizatinon of post-consumer textiles and clothing. Journal of Family and Consumer Sciences, 95(2), 33-37.

Van Birgelen, M., Semeijn, J., \& Keicher, M. (2009). Packaging and proenvironmental consumption behavior. Environmental and Behavior, 41(1), 125-146.

Van Damme, I. \& Vermoesen, R. (2009). Second hand consumption as a way of life: Public auctions in the surroundings of alost in the late eighteen century. Continuity and Change, 24, 275-305.

Van Ness, N. \& Cramer, J. (2005). Influencing product lifetime through product design. Business Strategy and the Environment, 14, 286-299.
Walter, E. E. (2008). Textile recycling attitudes and behaviors among college students (unpublished master's thesis). Eastern Illinois University, USA.

Ward, J. (2011). Political consumerism as political participations? In K. Brants \& K. Voltmer (eds). Political communication in postmodern democracy: Challenging the primacy of politics. Hampshire, UK: Palgrave MacMillan.

Winakor, G. (1969). The Process of clothing consumption. Journal of Home Economics, 61, 629-634.

Wright, J. (2014). The industries and countries still in the recession's grip. Forbes. Available at http://www.forbes.com/sites/emsi/2013/09/13/ for-metros-with-flourishing-economies-techsector-at-center-of-job-growth/

Xu, Y., Chen, Y., Burman, R., \& Zhao, H. (2014). Second hand clothing consumption: A cross cultural comparison between American and Chinese young consumers. International Journal of Consumer Studies, 38, 670-677.

Zauberman, G., Ratner, R. K., \& Kim, B. K. (2009). Memories as assets: Strategic memory protecttion in choice over time. Journal of Consumer Research, 35(Feb), 715-728. 